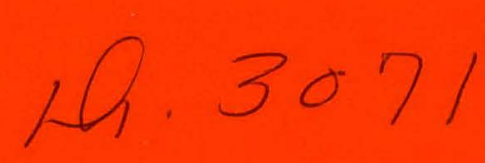

\title{
Problems in the Administration of State Solar Legislation
}

Michael Warren
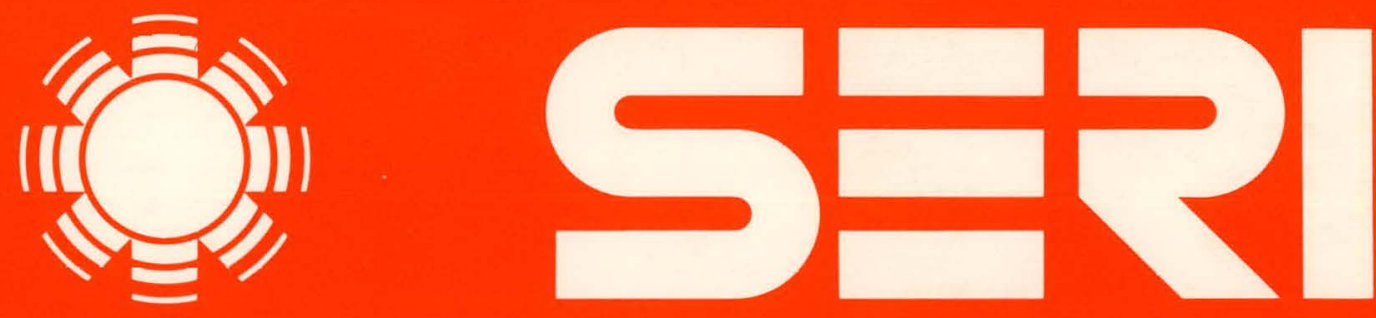

Solar Energy Research Institute A Division of Midwest Research Institute

1536 Cole Boulevard

Golden, Colorado 80401

Operated for the U.S. Department of Energy under Contract No. EG-77-C-01-4042

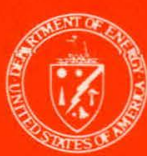




\section{DISCLAIMER}

This report was prepared as an account of work sponsored by an agency of the United States Government. Neither the United States Government nor any agency Thereof, nor any of their employees, makes any warranty, express or implied, or assumes any legal liability or responsibility for the accuracy, completeness, or usefulness of any information, apparatus, product, or process disclosed, or represents that its use would not infringe privately owned rights. Reference herein to any specific commercial product, process, or service by trade name, trademark, manufacturer, or otherwise does not necessarily constitute or imply its endorsement, recommendation, or favoring by the United States Government or any agency thereof. The views and opinions of authors expressed herein do not necessarily state or reflect those of the United States Government or any agency thereof. 


\section{DISCLAIMER}

Portions of this document may be illegible in electronic image products. Images are produced from the best available original document. 
Printed in the United States of America Available from:

National 'lechnical Information Service

U.S. Department of Commerce

5285 Port Royal Road

Springfipld, VA 2.2 .161

Price:

Microfiche $\$ 3.00$

Printed Copy $\$ 4.50$

NOTICE

This report was prepared as an account of work sponsored by the United States Government. Neither the United States nor the United States Department of Energy, nor any of their employees, nor any of their contractors, subcontractors, or their employees, makes any warranty, express or implied, or assumes any legal liability or responsibility for the accuracy, completeness or usefulness of any information, apparatus, product or process disclosed, or represents that its use would not infringe privately owned rights. 
UC CATEGORY: UC-59,60,61,62.63

PROBLEMS IN THE ADMINISTRATION OF

STATE SOLAR LEGISLATION

MICHAEL WARREN

JULY 1979

\section{Solar Energy Research Institute}

1536 Cole Boulevard

Golden, Colorado 80401

A Division of Midwest Résearch Institute

Prepared for the

U.S. Department of Energy

Contract No. EG $\cdot 77 \cdot \mathrm{C} \cdot 01 \cdot 4042$ 


\section{FOREWORD}

This paper on problems in the administration of state solar legislation was prepared by the Solar Energy Research Institute (SERI) to fulfill, in part, SERI's solar information dissemination function. The paper is part of the Market Development Branch Law Program, which is in turn part of the overall program of the Technology Commericalization Division.

This is the third of eight 1978 Summer Law Intern Papers sponsored by the SERI Law Program. The other seven address (1) the impact of the antitrust laws on the commercialization of solar heating and cooling, (2) licensing arrangements and the development of the solar energy industry, (3) legal and institutional implications of providing financial incentives to encourage the development of solar energy technologies, (4) legal considerations in the development and implementation of biomass energy technologies, (5) state approaches to solar energy incentives, (6) land-use barriers and incentives to the use of solar energy, and (7) utility rates and service policies as potential barriers to the market penetration of decentralized solar technologies. These eight studies are meant to raise and discuss the primary legal issues that are, or will be, generated by the commercialization of solar technologies.

The author of this paper, Michael Warren, was a student at the University of Denver Law School while he was participating in the 1978 Summer Law Intern Program.

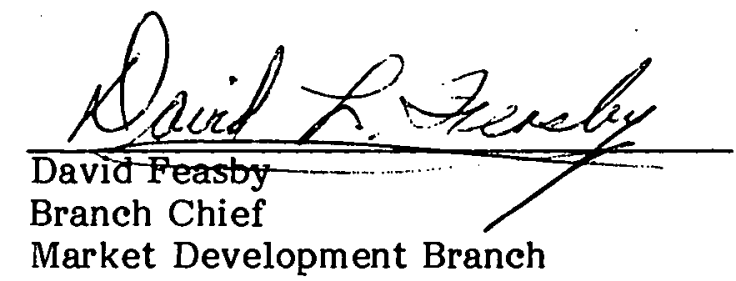

Approved for:

SOLAR ENERGY RESEARCH INSTITUTE

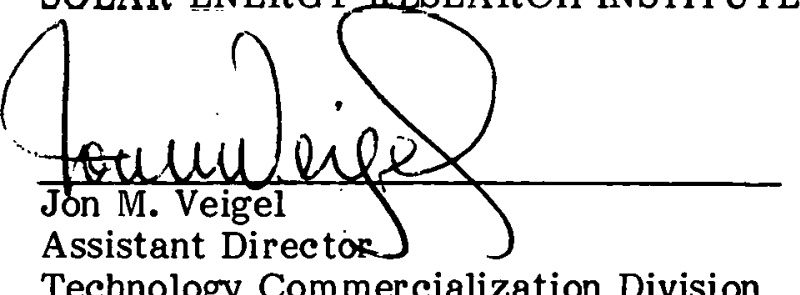




\section{SUMMARY}

A wave of legislation, designed to stimulate the development of solar technology as an alternate energy resource, has been enacted by state legislatures. Much of this legislation, although conceived with enthusiasm, was drafted and passed in a hasty manner. Such haste was due in part to the crisis atmosphere created by the realization that oil is not an endless supply of energy, and by this country's dependence on foreign oil, the supply of which is tied to political and economic factors beyond our control. Of ten, inadequate attention has been given to the implementation of solar legislation at the administrative level. Laws designed to foster the development of solar energy, if unclear or ambiguous, may be strangled by the resulting web of administrative rules, procedures, and interagency conflicts.

Some administrative difficulties may be inherent in solar energy legislation because of the nature and novelty of solar energy. Solar energy laws can be broadly classified as those which (1) stimulate research and development, (2) encourage solar installations by the creation of various governmental incentives such as tax exemptions, or (3) contribute to the elimination of institutional barriers to the use of solar energy, such as laws creating solar easements, modifying utility rate structures, or creating regulatory standards. Legislation that attempts to deal with such an immense range of problems will touch many different departments and agencies in state government. Thus, legislative tools allowing for proper administration of solar energy legislation become essential to the effectiveness of the legislation.

Nor are the states alone in their concern with solar energy. The Federal Government is also involved in extensive programs to foster the commercialization of solar technology, most recently through the statutes of the National Energy Act and the creation of standards affecting solar energy equipment. This results in administrative rules and regulations that the solar manufacturer, seller, installer, or consumer must face.

It is the goal of this paper to suggest methods by which state solar legislation can be drafted (or amended) to avoid the administrative difficulties that have slowed some state solar initiatives, and give full effect to legislatures' intentions, while combining state initiatives with federal solar programs.

Several common problems in state solar legislation that hinder its effectiveness are identified in this paper; inadequate definition of important terms, ineffective or unclear delegation of administrative responsibility to state agencies, and insufficient coordination with other state and federal solar programs. The experiences of three states (California, Oregon, and New Mexico) are focused on in this paper. 


\section{TABLE OF CONTENTS}

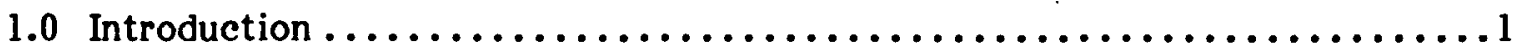

2.0 Overview of State Solar Legislation.......................

3.0 Federal Solar Legislation $\ldots \ldots \ldots \ldots \ldots \ldots \ldots \ldots \ldots \ldots \ldots \ldots \ldots \ldots \ldots \ldots$

4.0 Common Problems in State Solar Legislation $\ldots \ldots \ldots \ldots \ldots \ldots \ldots \ldots \ldots$

4.1 Inadequate Definitions ............................

4.2 Unclear Delegation of Legislative Authority $\ldots \ldots \ldots \ldots \ldots \ldots \ldots \ldots 7$

4.3 Lack of Intergovernmental Coordination..................

4.3.1 The Supremacy Clause ........................

4.3.2 The Commerce Clause ......................... 10

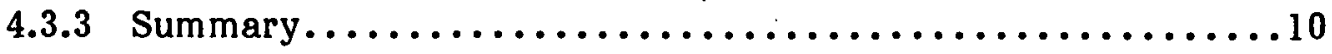

5.0 State Implementation Experience....................... 13

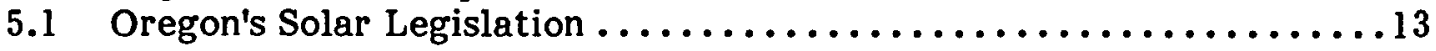

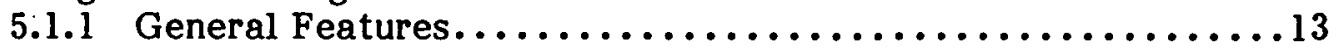

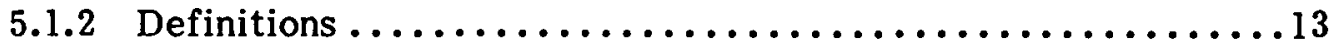

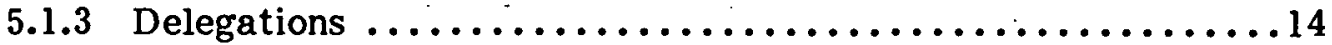

5.1 .4 Intergovernmental Coordination ..................... 14

5.1 .5 Conclusion ............................... 15

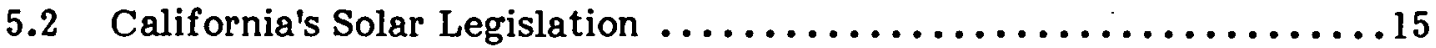

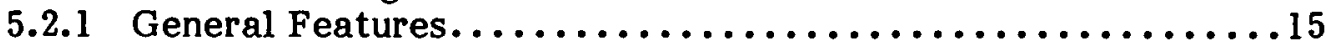

5.2 .2 Survey of California Legislation ................... 15

5.2.3 An Assessment of California Solar Legislation............ 16

5.2.4 Coordination of Governmental Efforts ...............22

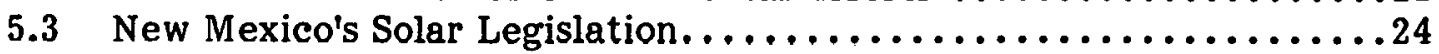

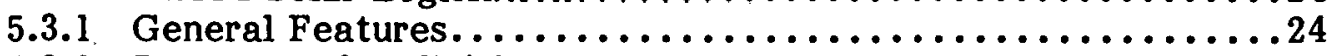

5.3.2 Problems of Definition and Delegation Under the

New Mexico Solar Code ........................24

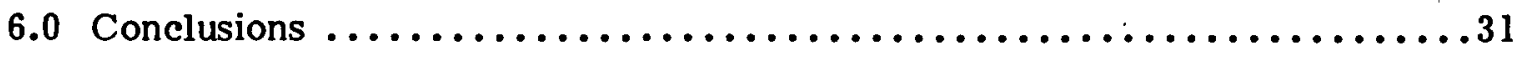

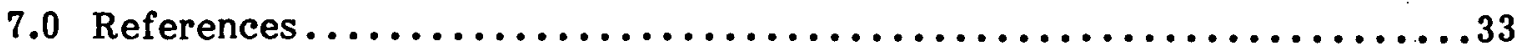




\section{SECTION 1.0}

\section{INTRODUCTION}

As a result of increasing awareness of the nation's energy crisis, a wave of solar legislation. designed to stimulate the development of solar energy technology as an alternate fuel source has been enacted by state legislatures. Much of this legislation, although conceived with enthusiasm, was drafted and passed in a hasty manner, due in part to the crisis atmosphere generated by the Organization of Petroleum Exporting Countries (OPEC) oil embargo of 1973 and 1974. Of ten, inadequate attention has been given to the implementation of solar legislation at the administrative level. Laws designed to foster the development of solar energy have at times been strangled by the resulting web of administrative rules, procedures, and interagency conflicts. The administrative difficulties that have resulted, in many cases, have created barriers to solar commercialization.

The states are not alone in their concern with solar energy. The Federal Government is also involved in extensive programs to foster the commercialization of solar technology, thereby creating yet another level of administrative rules and regulations facing the solar manufacturer, seller, installer, or consumer.

This paper suggests methods by which state solar legislation can be drafted (or amended) to avoid the administrative difficulties that have plagued some state solar initiatives, and to give full effect to legislatures' intentions, while coordinating state initiatives with federal solar programs. 
SEPI 


\section{SECTION 2.0}

\section{OVERVIEW OF STATE SOLAR LEGISLATION}

State solar laws can be divided into three broad categories: (1) those which foster solar research and development; (2) those which encourage solar installation by the creation of various governmental incentives; and (3) those which attempt to eliminate institutional barriers to the use of solar energy.

As of July 1978, 23 states had passed laws relating to research and development of solar technology [1]. These statutes commonly require a state agency to conduct studies concerning the potential of solar applications to supply the state's energy needs and to disseminate the results of such research [2]. Several states have funded solar demonstration projects. Others have required that performance standards be established for solar equipment, and have set up certification and testing programs to accommodate this requirement [3]. Such research and development statutes characteristically contain small appropriations.

In the second category of state solar legislation are those laws designed to promote solar development by the extension of various governmental incentives for solar applications to the public. The most common of these are tax incentives. As of early 1979, 34 states had enacted some form of property tax exemption for solar equipment [4]. Such statutes generally exempt the value of a solar system from being included as part of a structure's assessed valuation. Exemptions commonly equal the difference between the true cash value of the property equipped with the solar system and the value of the property without it. As of 1978,18 states had extended income tax deductions or credits to solar consumers [5]. The deductions scheme most of ten allows the cost of the solar system to be deducted from taxable income [6]. The less prevalent tax credit system allows the cost of a solar installation to be deducted from the amount of tax actually paid (up to a specified limit). Three thousand dollars is the highest amount allowed by any state solar tax credit [7]. Several states permit persons to amortize or depreciate solar equipment for tax purposes more rapidly than would be otherwise permitted by the state tax code [8]. Six states have offered various forms of sales and use tax exemptions on solar devices [9].

In addition to tax incentives, three states offer some form of solar loan program. Oregon, for example, extends the maximum limit of its home loans to veterans by $\$ 3,000$ if solar applications are utilized within the home [10]. Massachusetts has extended the amount that state chartered banks and credit unions are allowed to loan for home improvements if solar devices are employed [11]. California extends solar loans to victims of certain natural disasters [12].

In the final category of state solar legislation are those. statutes which attempt to eliminate institutional harriers to the use of solar energy [13]. These barriers include, but are not limited to, discriminatory utility rate structures, state and local building codes that do not provide for (or that prohibit) solar installation, and the fact that in many states impunity may be granted to an adjoining property owner who may shade a solar collector. Seven states have attempted to solve the solar access or "shading" problem by the recognition of privately negotiated "solar easements" [14]. Several have authorized or required zoning authorities and other land-use planning bodies to develop solar access plans or regulations [15]. One state [16] has attempted to use the prior appropriation and beneficial use doctrines borrowed from state water law to solve solar access disputes. 


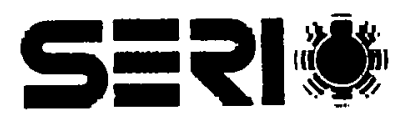




\section{SECTION 3.0}

\section{FEDERAL SOLAR LEGISLATION}

Prior to 1978, the federal solar effort focused primarily on research and development [17]. However, during the 1978 legislative session, Congress enacted the National Energy Act [18]. As a part of this Act, Congress passed the Energy Tax Act of 1978 [19], which allows an individual a nonrefundable tax credit for solar energy equipment used in connection with his principal residence. The credit amounts to $30 \%$ of the first $\$ 2,000$ of expenditures plus $20 \%$ of the next $\$ 8,000$ of expenditures. The maximum total credit is therefore $\$ 2,200$. Any excess credit derived in one tax year may be carried over through calendar year 1987. The credit is retroactive to April 20, 1977.

At the time of this writing, the Internal Revenue Service is in the process of drafting regulations implementing the solar tax credit. These regulations will identify qualifying solar equipment and procedures to be followed in obtaining the credit. It is uncertain how these regulations will impact the myriad of similar state regulations, or whether they will complement or follow the standard for solar systems previously promulgated by the Department of Housing and Urban Development [20], pursuant to the Solar Heating and Cooling Demonstration Act of 1974 [21]. 


\section{S\#PI}




\section{SECTION 4.0}

\section{COMMON PROBLEMS IN STATE SOLAR LEGISLATION}

Three typical problems' intensify the difficulties encountered by state administrative agencies in implementing solar legislation. They are : (1) inadequate statutory definition of key terms, (2) unclear delegation of responsibility to administrative agencies, and (3) lack of a requirem ent of intergovernmental coordination. The root of these problems can of ten be found in the language of the statutes themselves.

\subsection{INADEQUATE DEFINITIONS}

A significant problem in state solar legislation is the absence of definition of key terms. In many cases, statutes use basic terms such as "solar collector" without defining such a device. Where statutory definitions are given, they are frequently vague or ambiguous; e.g., solar heating systems may be either active or passive. These systems may actively collect the sun's energy by means of mechanical collectors and storage units, or may make use of the sun's rays by passive structural designs such as window and mass placement or building orientation. Several state statutes, considered exemplary by many, have neglected to address this rather important distinction, or to state explicitly whether the statutes are intended to encompass passive systems. In this area, confusion in administering a solar incentive that lacks clear guidance is virtually certain.

At the other end of the spectrum are those definitions that are too detailed. Such definitions cause a lack of the flexibility that solar laws need in order to be able to keep abreast of future designs and uses of solar energy systems, especially at this early stage of the industry's development. The creation of adequate definitions, before much experience has been gained with solar technology, is not a simple task. This has led to an attempt by many state legislatures to delegate the task of defining terms and the context in which they will be applied to subordinate administrative agencies. A second chronic difficulty with state solar statutes, confusing or inadequate delegations, has emerged as a result of this attempt.

\subsection{UNCLEAR DELEGATION OP LEGISLATIVE AUTHORITY}

Unclear delegations of authority to define terms and administer solar programs may be faulty on two grounds-one legal, the other, conceptual or political.

The delegation of power by a legislature to a subordinate governmental agency is governed by legal principles derived from the doctrine of separation of powers. Generally, these principles require that a legislature, when delegating authority to make rules and regulations, provide adequate standards defining the limits of the delegated authority. State laws differ, but tend to be more restrictive than federal law in determining the requirements of an adequate standard.

Particular states have enacted solar statutes that do not delegate responsibility to administer a program to any agency. An administrative regulation promulgated under such a statute may be subject to a challenge that the agency lacks the power to act since the legislature has not granted it such power. 
Even where a particular delegation passes legal muster, the choice of the agency to administer solar provisions is sometimes a source of difficulty. Delegations have been made to agencies without experience in the solar field, in spite of the fact that agencies with such experience existed within the state government. Other states have made delegations to multiple agencies, resulting in separate "solar bureaucracies" within the same state government. Lack of coordination between these agencies contributes in large part to the administrative immobility that appears to surround solar efforts in some states.

\subsection{LACK OF INTERGOVERNMENTAL COORDINATION}

The third problem of many state solar statutes is that they are not drafted in such a way as to compliment solar programs being conducted by other levels of government. Each state has its own definition of a solar collector and may define a solar system differently. A manufacturer of solar equipment thus faces the task of insuring that his equipment meets numerous criteria in numerous states, some of which might conflict.

This intergovernmental coordination problem has become particularly acute since the Federal Government has passed its own solar incentive package. The administrative guidelines or definitions ultimately adopted pursuant to the federal effort may conflict with some state regulations.

State solar standards and criteria might also create legal difficulties by operation of the Commerce and Supremacy clauses of the U.S. Constitution. A brief discussion of each clause is therefore in order.

\subsubsection{The Supremacy Clause}

The Supremacy Clause of the U.S. Constitution [22] ordains that acts of the Ferderal Government, whether in the form of a law, court decision, tresty, or administrative action, are the supreme laws of the United States [23]. The states have no power to impede or burden laws enacted by the Federal Government [24]. State laws that conflict directly with federal laws are preempted or nullified by the federal action [25]; state laws that merely interfere with federal actions are also preempted [26]. This preemption doctrine assures that conflicting regulation of conduct by various levels of government. is minimized [27].

The Supreme Court has devised several tests for determining whether federal actions preempt state actions. In Hines v. Davidowitz [28], the Court stated that the test was whether under the circumstances of a specific case the state action "stands as an obstacle to the accomplishment and execution of the full purpose and objectives of Congress" [29]. This test was further refined in Pennsylvania v. Nelson [30]. Speaking for the Court, Chief Justice Warren put forward a three-pronged test governing the resolution of preemption questions: the pervasiveness of the federal regulatory scheme, federal occupation of the field as necessitated by the need for national uniformity and the danger of conflict between state laws and the administration of federal programs [31]. It is noted that each prong of the preceding test is designed to ascertain the preemptive intent of Congress to occupy a certain field of regulation. In other words, in the absence of an expressed congressional intent to preempt, whether a particular state action is preempted by a federal action must be determined by a judicial determination of congressional intent [32]. 
Recent cases have demonstrated the Court's reluctance to strike down state regulations in the absence of a clearly manifested intent of Congress; a presumption of validity seems to have been conferred on state actions in the absence of a manifest congressional preemption. The court stated in New York State Department of Social Services v. Dublino [33]:

If Congress is authorized to act in a field it should manifest its intent clearly. It will not be presumed that a federal statute was intended to supercede the exercise of the power of the state unless there is a clear manifestation of intent to do so. The exercise of federal supremacy is not lightly to be presumed. [34]

The passage of federal standards and criteria revolving around various tax incentives might give rise to arguments that particular state solar regulations have been preempted by congressional action. For example, where state regulations forbid the sale or installation (through building or energy conservation codes) of solar systems that meet criteria established by the Federal Government for its tax credit, but do not meet corresponding state standards, it might be asserted that Congress has demonstrated its intent to foster the commercialization of solar technology in this country in order to lessen our reliance on nonrenewable energy resources. It has chosen to help accomplish this goal by instituting a tax credit for alternate energy applications, including solar energy. Congress has specified the type of solar devices that will reduce energy conservation in the United States and that are suitable for widespread commercialization by setting criteria for such equipment under the tax credit. State regulations forbidding the sale or installation of solar equipment (defined as adequate under the federal criteria, but which does not conform to state standards), unnecessarily impede the intent of the act to spur the widespread commercialization of solar technology, and therefore should be preempted.

This preemption argument might have carried some weight under earlier case law, particularly under the Hines and Nelson tests. However, it is very weak when viewed in light of the more recent Supreme Court statements on the subject, because no "manifest intent" to preempt state standards can be found in the solar provisions of the National Energy Act (NEA). In fact, the conference version of the NEA provided for the establishment of uniform energy efficiency standards for certain household appliances and expressly preempted any similar state standards [35]. This demonstrates that Congress (or at least the conferees) were well aware of the preemption question and chose not to address it in the sections dealing with the solar tax credit.

Moreover, a recent Supreme Court decision refused to preempt state regulations in a situation almost identical to the present. In New York State Department of Social Services v. Dublino [36], when faced with arguments very similar to the previous preemption argument, the Supreme Court upheld the State of New York regulation which conditioned receipt of federal Aid to Dependent Children (ADC) payments on the fulfillment of additional state requirements.

In sum, the solar equipment standards or criteria promulgated as a result of the passage of the federal tax credit will probably not preempt similar state standards, but will coexist with them. The case would be different if the Federal Government chose to promulgate uniform solar standards in order to encourage solar applications. However, as long as the federal standards apply only to a federal tax credit or other similar programs, the Doctrine of Preemption cannot be relied upon to solve the problem presented by multiple solar standards occurring at the federal and state level. States should, however, be aware of the potential problem and avoid it by requiring that state effurts are coordinated with fcderal solar activities. 


\subsubsection{The Commerce Clause}

The Commerce Clause of the United States Constitution [37] provides in relevant part that Congress shall have the power "to regulate commerce... among the several states ...." Even in the absence of congressional exercise of this power, the clause prevents states from erecting barriers to the free flow of interstate commerce [38]. A state may, however, pass laws or enact regulations that impede the flow of interstate commerce if they are designed to further some important state interest [39]. $\Lambda \mathrm{n}$ important state interest that is strong enough to warrant impeding the flow of interstate commerce is one that concerns itself with public health or safety [40], and does not discriminate in favor of intrastate interests [41].

The Supreme Court, in a case decided in February of 1.978, stated that:

Although the criteria for detemining the validity of state statutes affecting interstate commerce have been variously stated, the general rule that emerges can be phrased as follows: Where the statute regulates evenhandedly to effectuate a legitimate local public interest, and its effects on interstate commerce are only incidental, it will be upheld unless the burden imposed on such commerce is clearly excessive in relation to the putative local benefits. Huron Cement Co. v. Detroit, 362 U.S. 440, 443, 80 S. Ct. 313,4 L.Ed.2d 852. If a legitimate local purpose is found, then the question becomes one of degree. And the extent of the burden that will be tolerated will of course depend on the nature of the local interest involved, and on whether it could be promoted as well with a lesser impact on interstate activities. [42]

In the same case, the court went on to apply the preceding rule to invalidate a Wisconsin administrative regulation that restricted operation of trucks over 55 feet in length on state highways. (Interstate trucking companies had challenged the regulation as burdening interstate commerce). The Court found that the regulations placed a substantial burden on interstate commerce and could be said only to make a "speculative contribution to highway safety" [43].

In the light of this recent Supreme Court statement on the subject, it would seem that the various state standards which prohibited the sale $n r$ installation of nonconforming solar equipment might be challenged as impeding the flow of interstate commerce [44]. The fact that either preemption or commerce clause questions might arise over the promulgation of state solar standards points to the need for attention to intergovernmental coordination when enacting or amending state solar laws which establish such standards.

\subsubsection{Summary}

Pressures on state solar laws created by these problems have not yet resulted in amendments, at least in most jurisdictions, because the resulting disputes have not yet occurred; solar installations are still somewhat of an oddity in many localities. It is safe to assume, however, that this situation will soon change. The growth of solar technology in the past few years has been rapid. In 1976, the United States produced one million $\mathrm{ft}^{2}$ of solar collectors. In 1977, that figure tripled [45].

In the near future, it is anticipated that steps will be taken toward deregulation of the price of natural gas. Some estimate that this will result in a doubling of home heating 
bills [46]. This fact alone will spur solar installations. In addition, federal incentives such as the federal tax credit for solar installation may soon produce a desirable effect. Such factors, in conjunction with various state and local incentives, will further encourage solar applications.

As other energy sources become more expensive or less available, and the pace of solar commercialization quickens, many states will meet the resultant rapid solar development with inadequate legal structures. The heady initial attempts at creating a legal framework for solar technology will have to give way to a more coordinated and well-defined system. 


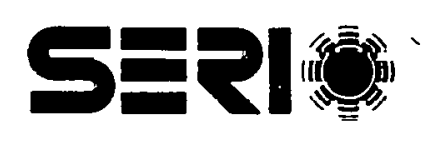




\section{SECTION 5.0}

\section{STATE IMPLEMENTATION RXPERIENCE}

This section discusses the implementation difficulties encountered by three states which have enacted solar energy legislation: Oregon, New Mexico, and California. These particular states were chosen because they represent typical experiences in confronting (or failing to confront) the problems of definition, delegation, and intergovernmental coordination.

\subsection{OREGON'S SOLAR LEGISLATION}

\subsubsection{General Features}

The state of Oregon has long been among the nation's frontrunners in its commitment to the development of solar energy. Salient features of the state's solar legislative initiative include:

- A Central Energy Agency: In 1975, the Oregon legislature created the Oregon Department of Energy (ODOE), charged with oversight of the state's energy resources programs [47].

- Solar Property Tax Credit: In 1975, the legislature exempted property equipped with a "solar energy heating or cooling system" from ad valorem taxation in an amount "that equals any positive amount obtained by subtracting the true cash value of the property (as if it were not equipped with a solar heating or cooling system) from the true cash value of the property with the solar heating or cooling system" [48]. The exemption terminates in 1998.

- Solar Standards: In 1977, the legislature required the Department of Energy to develop rules prescribing minimum performance criteria for "alternate energy devices for dwellings" [49]. The statute's definition of alternate energy devices includes solar energy systems [50]. The same statute requires the Department of Energy to certify solar energy systems that meet the minimum performance criteria for solar systems required to be developed by ODOE [51].

- Income Tax Credit: Oregon 'extends a tax credit equal. to $25 \%$ of the cost of solar systems or $\$ 1,000$ for alternate energy systems certified by the ODOE as conforming with the state's performance criteria for such systems [52]. The credit will terminate in 1985 [53].

- Veterans Loan for Solar Installations: In 1977, the legislature authorized the state Office of Veterans Affairs to loan up to $\$ 3,000$ for the purpose of installing an alternative energy device for a home [54]. The statute's definition of "alternate energy device" includes solar energy systems [55].

\subsubsection{Definitions}

The Oregon solar code is, in part, remarkably consistent in its definitions of important terms. Alternate energy systems are defined in the same way for both the ODOE's 
certification and standards program and the Veterans' Loan Program [56]. By requiring that alternate energy systems eligible for income tax credits be certified by the ODOE, the legislature has assured that tax credit definitions are consistent with those found in other solar incentives. However, there is no distinction in the Oregon solar code between active and passive systems. The uniform definition of alternate solar energy device states:

\begin{abstract}
Alternative energy device means any system, mechanism, or series, of mechanisms which use solar radiation, wind, or geothermal resources as a source for space heating, water heating, cooling, electrical energy, or any combination thereof for a dwelling which source meets or exceeds $10 \%$ of the total energy requirements for the dwelling. [57]
\end{abstract}

Thus, insofar as statutory language is concerned, the question of whether "alternate. energy systems" include passive solar systems remains npen. Some confusion in admini3. tration is likely to result from such statutes.

Nor is the definition of "alternate energy devices and systems" adopted by all state solar statutes. The Oregon statute exempting solar systems from property taxation fails to define the term "solar systems" [58], thus leaving unclear whether passive solar systems are exempt, or whether the performance criteria developed by ODOE are applicable.

\title{
5.1.3 Delegations
}

The Oregon solar income tax credit, property tax exemption, and Veterans' Loan Program are each administered by a different state agency pursuant to delegations contained within each separate statute. The Office of Veterans Affairs is responsible for the veterans' loans [59]; the Department of Revenue, for the property tax exemption [60]; and the Department of Energy is responsible for certifying solar systems eligible for the income tax credit. [61].

This multiplicity of delegation has resulted in separatc administrative regulatiuns belng promulgated by each agency. Even though the Office of Veterans Affairs is empowered to contract with ODOE for certifications of alternate energy devices eligible for the veterans' loans [62], it has chosen not to do so, promulgating its own rules governing system eligibility [63]. As a result, separate regulations exist for alternative energy devices in each agency responsible for administering statc solar incentives.

\subsubsection{Intergovernmental Coordination}

The only place in the Oregon solar code where intergovernmental coordination is mentioned is in the statute dealing with the establishment of minimum performance criteria for alternate energy systems [64]. ODOE is required to take into consideration standards of federal performance criteria prescribed under the Solar Heating and Cooling Act of 1974 [65]. If the federal solar tax credit does not adopt the Housing and Urban Development (HUD) interim guidelines, solar consumers in Oregon might be faced with yet another layer of administrative regulations governing their system's eligibility for various governmental incentives, $a$ vexation at best. 


\subsubsection{Conclusion}

Oregon's solar legislative package suffers from multiple delegations that have created multiple administrative regulations governing solar systems. The statutes are commendable in their uniform use of definitions. These definitions are, however, silent as to the active/passive distinction. The solar code seems, in most part, to pass over the problem of intergovernmental coordination of efforts.

\subsection{CALIPORNIA'S SOLAR LEGISLATION}

\subsubsection{General Features}

Among the states, California is of ten regarded as the nation's leader in its commitment to the development of alternate energy sources, especially solar energy. California's governor has repeatedly expressed the state's overriding commitment to the development of solar energy resources [66].

The California executive budget for fiscal year 1978-1979 raises the total of state expenditures on alternate energy projects to $\$ 15$ million. Sixty percent of these funds will go towards solar development [67].

The state energy agency, the Energy Resources Conservation and Development Commission (hereinafter the Commission or ERDC) has set a goal of 1.5 million solar energy applications in California by 1985 [68]. By way of contrast, the National Energy Plan [69] sets a goal of only 2.5 million solar installations by 1985 .

\subsubsection{Survey of California Legislation}

To date, the California legislature has enacted a variety of statutes creating programs intended to encourage the development of solar energy within the state. Salient features of the California solar statutory scheme include:

- A Central Energy Agency: The Energy Resources Conservation and Development Commission was created by the legislature in January 1975 [70]. The Commission is charged with integrating and clarifying existing functions relating to energy resource conservation and development, including alternate energy sources. Responsibility for forecasting and assessment of energy conservation and supply, energy site certification, research and development, and enforcement are consolidated in the Commission. Within the commission, a "Solar Office" has been created to direct the Commission's role in solar energy development.

- Research and Development: In 1977, the California legislature passed Assembly Bill 1512 [71], which required the Commission to establish and coordinate a program of research and development to spur the "Expansion and accelerated development of alternate sources of energy," including solar energy [72]. The Commission was authorized to conduct alternate energy demonstration projects and to "prepare for mass market development of solar systems by developing designs for prototype solar housing ..." [73]. The Commission was also required to develop a manual of "design types, costs, performance and evaluation procedures" for solar systems [74]. 
- Solar Standards: In Assembly Bill 1512 the legislature required ERDC to develop and adopt regulations governing solar devices [75]. The regulations include standards for "testing, inspection, certification, sizing, and installation of solar devices." The Commission was further empowered to promulgate regulations to enforce the standards including, but not limited to, the establishment of a solar equipment certification program, requirements for outside inspection of solar devices, and regulations prohibiting the sale of solar devices that do not meet minimum requirements for safety and durability [76]. The statute also forbids the Commission from "precluding" any person from developing, installing, or operating a device on his or her own property. Violation of the regulations promulgated by the Commission may be enjoined by court order. ERDC was also directed to coordinate the adoption of standards and regulations with Federal agencies including HUD, DOE and the National Bureau of Standards [77].

- Tax Credits: In 1976, the Callfornla legislature enacted a $10 \%$ income tax credit for installation of solar equipment. In 1977, the legislature amended the existing tax credit to increase that amount. As currently enforced [78], the credit provides $55 \%$ of a solar system cost, including the cost of conservation measures taken in conjunction therewith, up to a maximum of $\$ 3,000$ for residential buildings [79]. Solar applications in nonresidential buildings that cost more than $\$ 6,000$ are extended a tax credit equal to the greater of $\$ 3,000$ or $25 \%$ of the cost of solar energy systems [80]. The tax credits are only available until 1981. If a consumer takes advantage of the federal tax credit, the state credit will be reduced so that the combined credit shall not exceed $55 \%$ of equipment costs [81].

- Building Codes: In 1976, the legislature suthorized (though it did not require) local governments to enact regulations requiring that new buildings be constructed in a manner permitting the installation of solar heating devices [82]. If such regulations are enacted, they must specify a range of permissible roof pitches and directional alignments that optimize the efficiency of solar energy collection.

- Solar Loan Program: During its 1978 session, the California legislature created a solar loan program that will extend $\$ 2,000$ interest-free loans for solar applications to victims of natural disasters declared after July 1, 1977 [83]. \$200,000 was appropriated to establish a revolving loan fund to finance the program. The loan program will terminato on December 3l, 1880 [81]. The loan fund is to be administered by the California Department of Housing and Community Development. The Energy Resources and Development Commission is to establish criteria for solar applications that will qualify for the loans [85].

A property tax exemption for solar energy systems was passed by the legislature in 1977 [86], subject to voter approval. The voters turned down the exemption in the primary election of 1978 . 


\subsubsection{An Assessment of Califomia Solar Legislation}

\subsubsection{Adequacy of Definitions}

California solar statutes lack an adequate definition of key terms, particularly with regard to the active/passive distinction. The only California statute which clearly drew that distinction was the California Research and Development Act [87], which required the Energy Resource and Development Commission (ERDC) to establish standards regarding solar energy systems. The Act, in its definition section, distinguished among "passive thermal systems, semi-passive thermal systems, and solar systems" [88].

The definition of solar systems contained in the solar tax credit statute [89] was ambiguous as to whether a passive system was a "solar system" eligible for the tax credit. Likewise, neither the statute allowing local governments to enact regulations requiring new buildings to be constructed to accommodate "solar devices" [90], nor the act establishing the solar loan program [91], made distinctions between active and passive systems or devices.

The problem of inadequate definition in California solar statutes is not limited to the active/passive distinction. Important terms such as the "costs" that are eligible for the solar tax credit are also defined in a vague and ambiguous manner [92]. A review of the Commission's efforts to establish guidelines governing the administration of the state solar income tax credit will exemplify the difficulties caused by lack of adequate definitions in the California solar legislative scheme. Though important 1978 amendments have clarified the eligibility of passive systems [93], the other problems discussed in the following paragraphs continue.

The California solar tax credit statute required the Commission to establish guidelines and criteria for solar systems eligible for the tax credit. The statute thus defined a solar system:

The term solar energy system means equipment (1) which uses solar energy to heat or produce electricity; and (2) which has a useful life of at least three years. [94]

The legislation further prescribed that the amount of the credit allowed should be 55\% of the cost (including installation charges but excluding interest charges) incurred by the taxpayer installing any solar energy system on premises in California [95]. The statute specified that "energy conservation measures" [96] applied in conjunction with solar energy systems shall be considered part of the solar system and eligible for the tax credit [97]. The Commission was delegated responsibility for defining all eligible conservation measures.

The task of drafting regulations implementing the solar tax credit fell to the Solar Office within the Alternative Division of the Commission. The Solar Office, in attempting to promulgate eligibility criteria, was initially faced with determining whether passive systems were within the scope of the definition of solar systems provided by the statute. After considerable staff disagreement [98], the office promulgated regulations [99] that provided that passive systems were, in certain circumstances, eligible for the credit. These rules allowed tax credits for solar glazing material on south facing walls and roofs, movable insulation (such as shutters to prevent heat loss), the full cost of measures to provide shading of a structure, solariums and greenhouses, thermal mass, and thermal roof ponds [100]. 
The Solar Office also felt that no tax credit should be given to a solar system unless installed in conjunction with other energy conservation measures. Otherwise, the energy saved by the solar system might not be maximized and could be partially offset by energy lost due to inadequate insulation, weather stripping, or other energy wasting defects. Although the tax credit statute appeared to allow no more than the cost of cursory conservation measures to be included in the cost of the eligible solar system, the Solar Office proposed (and the Commission adopted) regulations requiring that certain "energy conservation measures" be taken in order to qualify for the solar tax credit [101]. The cost of these additional conservation measures may run into hundreds of dollars.

In itself, the conservation requirement is quite rational, perhaps even necessary. It precludes the state from extending credits for costly solar systems producing total energy savings that could be better achieved by a relatively inexpensive attic insulation. The difficulty lies in the fact that the statute authorizing the regulation does not explicitly require that such energy conservation measures be taken as a prerequisite to obtaining a credit. Instead, the statute merely states that energy saving efforts be computed as part of the cost of a solar system. The regulations requiring conservation measures may therefore be subject to criticism on the grounds that the administrative regulations requiring such measures were beyond the scope of the legislature's intent and, therefore, invalid as ultra vires.

This same criticism could apply to a challenge of the regulations that qualified passive systems for the tax credit, because the statutory definition of "solar systems" contained in the tax credit legislation did not clearly encompass passive applications. In fact, the California code distinguished between active and passive solar systems only in the Research and Development Act discussed earlier in this paper, in which "solar energy systems" were clearly distinguished from passive and semi-passive systems.

Although a definition of a solar system in one section of the code cannot be said to control the use of that term in another, the fact that the legislature clearly distinguished between active and passive systems in an earlier statute demonstrates that the legislature was aware of this distinction. It did not draw this distinction in a later sertinn. Was this by design? Was the omission merely an accident of statute drafting, indicating no intent to exclude passive systems? The fact that there are no clear answers to these questions is indicative of a weakness in the statute.

The Solar Office has also interpreted the Act to allow the maximum $\$ 3,000$ credit for each solar energy system in use. Thus, a taxpayer may claim as much as $\$ 3,000$ for a space conditioning system, $\$ 3,000$ for a hot water system, and $\$ 3,000$ for a swimming pool heating system, for a total credit of $\$ 9,000$ [102]. The Solar Office also proposed (and the Commission promulgated) regulations requiring that a one-year manufacturer's warranty be extended on all solar equipment in order for it to be eligible for the tax credit [103], though the statute cannot easily be read to require such a warranty [104]. The regulations including passive systems as eligible for the tax credit, requiring that energy conservation measures be taken in conjunction with solar system installations, requiring a one-year warranty, and most of all, allowing a maximum credit for each solar system included on a taxpayer's premises, may be challenged as beyond the scope of the legislature's intended grant of power [105]. Although it might be asserted that all of the preceding regulations are legitimate interpretations of legislative intent, and perhaps even necessary to effective implementation of the tax credit, the fact that cogent arguments can be raised against their validity points to an unnecessary weakness. Such issues were the focus of much of the debate carried on during the public hearing that preceded the adoption of the regulations [106]. Clear definition of basic terms within the tax credit statute itself could have easily avoided the problems that "cloud" the validity of the Commission's criteria. 
Depending on one's bias, solar definitions indicating the legislature's intent could have limited the "largess" with which the tax credit was being administered, or conversely allowed administrators to promulgate regulations insuring that the credit was effectively implemented-without having to make leaps of interpretive logic in translating a statute in to viable administrative regulations.

Recognizing that the weakness of the administrative regulations is caused by inadequate definitions, the Commission lobbied for legislation that would amend the existing tax credit statute(s) to provide a clearer indication of legislative intent. This effort resulted in the introduction of a bill on April 3,1978, which was enacted in September of that year [107]. The bill substantially modified the existing tax credit statute and thereby eliminated several of the problems stemming from the definitions discussed previously. The bill enlarged the definition section of the Act to specifically encompass passive solar systems as well as wind and photovoltaic applications. The definitions used are almost identical to those used in the Research and Development Act discussed in earlier paragraphs.

The definition section of the new bill reads in part, as follows:

(6) (A) Solar energy system means the use of solar devices for the individual function of: (i) domestic, recreational, therapeutic, or service water heating; (ii) space conditioning; (iii) production of electricity; (iv) process heat; (v) solar mechanical energy; and (vi) wind energy for the production of electricity or mechanical work.

The term solar energy system shall include, but is not limited to, passive thermal systems, semipassive thermal systems, active thermal systems, photovoltaic systems and wind-driven systems.

(B) Eligible solar energy systems shall have a useful life of not less than three years.

(7) Solar device means the equipment associated with the collection, transfer, distribution, storage and control of solar energy. In the case of a solar device associated with two or more solar energy systems, the credit allowed for the solar device may be taken for any one of the systems, or divided equally between them.

(8) Passive thermal system means a system which utilizes the structural elements of the building, and is not augmented by mechanical components, to provide for collection, storage, and distribution of solar energy for heating or cooling.

(9) Active thermal system means a system which utilizes solar devices thermally isolated from the living space to provide for collection, storage, and distribution of solar energy for heating or cooling.

(10) Semipassive thermal system means a system which utilizes the structure of a building and is augmented by mechanical components to provide for collection, storage, and distribution of solar energy for heating or cooling. [108]

These definitions address, if they do not entirely solve, the active/passive question discussed earlier. They are commendable in that regard. The bill does not, however, 
abate the controversy that surrounds the extension of a maximum credit for several different systems utilized by one structure or premise. Thus, legislative authority for such action must be implied, thereby supplying a focal point for continued argument. If the legislature envisions the granting of separate tax credits for each solar system, it could specifically state so. If it does not, it could state that the extension of a maximum credit of $\$ 9,000$ is beyond the intent of the legislature.

The bill does not solve the problem caused by the administrative regulations requiring energy conservation measures as a prerequisite for system eligibility. The bill merely addresses additional criteria for eligible conservation measures; it does not specifically require that they be taken. In addition, the bill does not provide for the extension of a full one-year manufacturer's warranty on solar equipment as required by the Commissioners eligibility criteria. Controversy may therefore continue over this point.

In sum, the tax credit bill should be praised for distinguishing between active and passive systems, thereby more clearly indicating legislative intent regarding implementation of the tax credit. It has helped solve the problem of multiple definitions by repeating the definitions used in the Research and Development Act, thus fostering a greater consistency throughout the solar legislative scheme.

The bill, however, neglects several important problems related to inadequate definitions. These must await further legislative or court action. It should also note that by repeating the definitions in the Research and Development Act, the bill carries the weakness of those definitions into the tax credit section.

The lesson to be learned from the California experience with definitions is obvious. Care should be taken when enacting solar legislation to ensure that it does not have to be amended at a later date, at least not in order to solve implementation problems that could have been avoided.

\subsubsection{Velegation Problcms}

The ensuing discussion of the influence of statutory delegations in the implementatinn of Callfornia's solar legislation focuses primarily on the experience obtained by state agencies in administering the solar tax credit and the Solar Research and Development statute.

The California Research and Development Act, as enacted in 1977, repuiren that uniform standards be developed for solar devices and delegated responsibility to accomplish this task to the ERDC [109]. Pursuant to this delegation, the Commission has prepared performance and installation standards for active solar devices, and established a testing and certificaion program (TIPSE), to measure the extent to which particular solar devices meet the standards [110]. The Commission has not yet formally adopted these regulations, but is expected to do so in the near future.

The legislature's choice of the ERDC as the responsible agency has much to commend it. The Cuillinission is well-financed, possesses the expertise necessary to accomplish the goals of the Act, is a statutorily created agency, and has a demonstrated commitment to the development of solar energy.

Although the legislature's choice of a delegee agency to administer the California Research and Development Program of 1977 was both simple and exemplary, the 
selection of an agency to administer the tax credits (passed in 1976) did not present such a clear-cut choice. Originally, the state taxing agency (the Franchise Tax Board) seemed like a logical delegee agency; since the statute dealt with taxes, the taxing agency should administer it. Thus, in 1976, the legislature delegated the responsibility for development of regulations implementing the tax credit program to the Franchise Tax Board [111]. However, it soon became apparent, in the view of various solar advocates, that the Franchise Tax Board might not be able to effectively implement the goals of the tax credit. The Franchise Tax Board had no technical expertise regarding solar systems, nor did its budget allow development of such expertise. Solar advocates argued that its institutional bias was toward protecting the public finances as opposed to fostering the growth of solar development. As a result of these criticisms, when the legislature amended the tax credit bill in 1977 , it modified the prior delegation to read:

(i) ... the Energy Resources Conservation and Development Commission shall ... establish guidelines and criteria for solar energy systems which shall be eligible for the credit provided by this section. The Franchise Tax Board shall prescribe such regulations as may be necessary to carry out the purposes of this section. [112]

The same language was also added to $\mathrm{S} 23601(\mathrm{~g})$, extending the credit to corporations.

This "split delegation" promoted friction between the two delegee agencies in creating regulations governing the tax credit. In setting eligibility criteria, the Commission took a rather expansive view of the intent of the legislature as derived from the language of the Act. It promulgated criteria including passive systems, requiring energy conservation measures and warranty requirements, as well as allowing a maximum credit for each solar system installed. The Franchise Tax Board, on the other hand, felt the expansive reading given the Act by the ERDC was not warranted by the Act's language, and opposed the criteria proposed by the Commission, preferring to exercise any benefit of doubt regarding the meaning of the Act in favor of the taxpayers' pocketbooks [113].

The Act's language provided that "the Franchise Tax Board shall prescribe such regulations as they may be necessary to carry out the purposes of this section [114]. Final interpretations as to the intent of the Act were, in the Board's view, to be made by the Franchise Tax Board. In the end, the dispute was resolved in favor of the position maintained by the Solar Office; the Tax Board promulgated regulations incorporating Solar Office criteria as proposed.

Although the difficulties arising because of the "split decision" in California were resolved at the administrative level without much difficulty, this would not necessarily always be the case. Friction between competing administrative agencies over the administration of a solar program could break out in overt "turf wars" that could hinder the effective implementation of a solar program. Moreover, interagency disputes occurring during the public hearing process preceding the adoption of rules and regulations, could provide solar program critics with an excellent forum for continued attack.

The problems inherent in a split delegation (if it cannot be avoided altogether) could be solved simply by including language in the delegation clearly specifying the roles of each agency, and perhaps by naming a "lead agency" whose final determination will bind all others. This could have been accomplished in the California statute by language specifically requiping the criteria promulgated by the ERDC to be promulgated by the Franchise Tax Board. 
It should be noted that the same sort of "split delegation" was contained in the statute creating the solar loan program. The ERDC was required by the Act to set eligibility criteria and the Department of Housing and Community Development was required to promulgate rules and regulations to eff ectuate its intent.

The statute requiring the Commission to set eligibility criteria under the loan program stated in part: "Only installations of a type approved by the Commission shall be eligible for financing" [115]. This statement helps alleviate problems encountered under the tax credit, regarding which agency's interpretation would prevail. Only systems approved by the Commission would qualify for the loan-a much stronger delineation of agency responsibility than that contained in the tax credit delegation.

The dispute between the Franchise Tax Board and the ERDC presents an excellent case history illustrating how the choice of an administrative agency can influence the direction and development of a solar program. By delegating to the ERDC a role in the formulation of regulations governing the tax credit, the legislature (perhaps inadvertently) assured an enthusiastic and expansive administration of the solar tax credit. If the legislature had chosen to allow the Franchise Tax Board to continue to administer the tax credit, as was the case until the 1977 amendment requiring the ERDC to set criteria, the administration of the solar tax credit would most likely have been more restrictive. Attention to the choice of a delegee agency is therefore an important part of the drafting (or amending) of a solar statute.

In summary, the difficulty with delegation in the California statutes derives primarily from split delegation. Any resulting problems could easily be remedied. The delegations are otherwise commendable in the uniform choice of an experienced and knowledgeable delegee agency.

\subsubsection{Coordination of Governmental Efforts}

\subsubsection{Intergovernmental Coordination}

Among Cullfornia statutes, references to intergovernmental coordination occur only in the Research and Development Act and the tax credit statutes.

The Research and Development Act requires the ERDC to "confer" with officials of various federal agencies to coordinate, inter alia, the adoption of regulations establiahing standards for solar devices [116]. The solar tax credit provides in relevant part:

Subject to the dollar limitations provided in paragraphs (2) and (3) of subdivision (a), if a federal income tax credit is enacted for costs incurred by a taxpayer for the purchase and installation of a solar energy system system as defined in this section, the state credit provided by this section shall be reduced so that the combined effective credit shall not exceed $55 \%$ of such costs, not withstanding the carry-over provisions of subdivision (f). [117]

Commission personnel have been in informal and somewhat continuous contact with federal agencies regarding the development of state solar standards. Whether this sort of informal contact will result in actual coordination of standards developed by the Federal Government under the federal tax credit or other solar programs, remains to be seen. 
The weakness of this type of coordination mandate lies in the fact that it does not require the coordination of state standards with similar federal standards and criteria. It is still conceivable that conflicting standards may be developed by California and the Federal Government, hindering the effectiveness of both efforts, regardless of how much "conferring" has taken place. A statutory requirement that the Commission set (or amend) regulations so as to conform with federal standards and criteria would completely avoid this difficulty. Of course, it would not solve the problem if California's legislature wished to take an approach differing from the federal approach; e.g., by encouraging a broader range of technologies.

It should also be noted that the California tax credit statute does not require that eligibility criteria developed thereunder conform to similar criteria being developed for the federal tax credit or other federal programs. A solar consumer might therefore face the problem of attempting to obtain solar equipment that meets conflicting criteria in order to take full advantage of both credits. The coordination of criteria would allow both federal and state credits to work together to more effectively foster commercialization of solar technology.

In its authorization to local governments to adopt rules and regulations (building codes) permitting installation of solar equipment, the legislature failed to require coordination between these local regulations and similar regulations promulgated by state agencies. It is possible, therefore, for local governments to adopt local standards governing the installation of solar equipment. These regulations could easily conflict with those of the ERDC in setting similar statewide standards. The state could have easily required that local building standards conform with those promulgated by the state ERDC. In this fashion, the legislature could have not only fostered coordination between local and state efforts, but also provided an effective local enforcement mechanism for standards promulgated by the ERDC under the Research and Development Act.

\subsubsection{Intragovernmental Coordination of Efforts}

Although the obvious intent of the legislature, in enacting the Research and Development Act, was to create some form of uniform statewide criteria for solar devices, no other state solar statute requires use of these criteria. The tax credit states that the Commission should set criteria governing solar devices that are eligible for the credit. It does not require that this criteria conform to the standards developed under the Research and Development Act. The same is true in the case of the solar loan statute.

A simple reference to the solar equipment standards developed by the ERDC would insure coordination of criteria [118]. It might be asserted that delegating the ERDC to set criteria for the tax credit, as well as to develop uniform standards under the Research and Development Act, assures proper coordination of these efforts. However, cooperation between state agencies is no more prevalent nor easy to achieve than is cooperation between layers of government. A statutory requirement will more likely insure that interagency coordination occur.

In most respects, the California solar statutory scheme is satisfactory. It suffers from problems of delegation, definition, and intergovernmental coordination, though not to the same degree as many other state solar codes. With the addition of a few simple modifications, it could serve as a fine example upon which other states could model their solar legislative initiatives. 


\subsection{NEW MEXICO'S SOLAR LEGISLATION}

\subsubsection{General Features}

The following is a summary of provisions of the New Mexico Solar Legislative Scheme.

- Central Energy Agency: As part of a general reorganization of state government, in 1977 the legislature consolidated a number of state agencies to form the Department of Energy and Minerals (DEM) [119]. DEM is required to administer all laws and exercise all functions formerly administered by the Energy Resources Board [120]. Prior to the creation of DEM, the Energy Resources Board was charged with oversight of the state's Solar Research and Development Program. This responsibility now lies with DEM.

- Solar Kights: During the 1977 legislative session, the state legislature enacted the New Mexicn Solar Rights Act [121l. Thr. Act purports to protect a ivlur user's access to the sun by application of the traditional water law concepts of prior appropriation and beneficial use. At least two local governments [122] have enacted ordinances protecting solar access. Neither use the water law concepts put forward by the State Solar Rights Act.

- Income Tax Rebates: New Mexico extends an income tax credit of $25 \%$ of the cost of "solar equipment" used in "principal residences"-not to exceed $\$ 1,000$ [123]. If the amount of the credit exceeds a taxpayer's liability, the excess is refunded to the taxpayer [124].

- Income Tax Rebate for Solar Irrigation Systems: Tax credit with a rebate provision is extended for the "cost of equipment used for construction of a solar energy system for irrigation pumping purposes." The tax credit (or rebate) may not exceed $\$ 25,000$ [125].

- Solar Research and Development: In 1975, the state legislature enacted the Energy Research and Development Act [126]. The Act established a special fund entitled the "Energy Research and Development Fund", to finance solar research and development [127]. The legislature in 1977 appointed $\$ 2.5$ million from the state's Mineral Severance Tax Fund to the Energy Research and Development Fund [128]. The Act also created a committee composed of gubernatorial appointments to review proposals submitted for funding [129]. The Energy Resources Board (now absorbed by DEM) was given responsibility to administer the special fund by drawing regulations regarding research contacts, coordinating reguests for funding, and providing staff support for ths. review committee [130].

\subsubsection{Problems of Definition and Delegation Under the New Mexico Solar Code}

New Mexico solar statutes suffer from inadequate statutory definitions and delegations. These twin difficulties manifest themselves clearly in the state's Solar Rights Act and its solar tax credits. For brevity's sake, the following discussion will focus only on these two statutes, which form the heart of the New Mexico solar program. 


\subsubsection{The New Mexico Solar Rights Act.}

The New Mexico Solar Rights Act [131] attempts to utilize the principles of "prior appropriation" and "beneficial use" to solve solar access problems. This concept has been criticized chiefly on the grounds that sunlight and water are entirely different entities; water law simply does not fit the problems of solar access [132].

For example, one person's right to use water does not interfere with the development of adjoining land to the same extent as does a right to the unobstructed rays of the sun. It is not likely that a single solar hot water heater would stop development of a children's burn center. Critics argue that centuries of English and American property law are premised on the idea of free use of property; guaranteed solar access unnecessarily conflicts with more traditional property rights [133].

Although the original bill contained specific language requiring that the state water law be applied in adjudicating solar access disputes, the State Water Engineer disapproved of this language. It was perceived to create an added burden on his department (the bill contained no appropriation), and the language was omitted from the text of the Act when it was finally passed. Thus, the statute does not require that water law system be used to resolve solar access disputes. In fact, it might be argued that the removal of this language from the original bill signaled the legislature's intent that state water law principles were not to be applied.

As currently enacted, the Act begins with a definition of a solar collector and recognizes a solar property right, which it defines as "an unobstructed line-of-sight path from the solar collector to the sun." The Act further declares that this property right is "to be encouraged and regulated by the laws of the State," and that the concepts of "beneficial use" and "prior appropriation" are to be used in settling solar access disputes [134].

In a later subsection, the Act states that "unless singular overriding State concerns exist, permit systems for the use of solar energy shall reside with county and municipal zoning authorities." Thus the legislature, in one paragraph, has declared that solar rights are to be regulated by the state. Several paragraphs later, it declares that "permit systems for the use of solar energy should reside at the local level." "The statute nowhere defines a permit system, nor does it specifically mandate that such systems be created at the local level (the Act only states that they shall reside there). The language of the Act is susceptible, therefore, to the following interpretation: the statute states that solar access is a property right to be regulated by the laws of the state. The legislature has never enacted such laws. Although permit systems are mentioned, the Act merely states that they shall reside with local zoning authorities once created. Therefore, the legislature must enact additional laws to create such permit systems.

Furthermore, no right can exist without a permit, because a permit is necessary to insure that the exercise of a solar right does not unnecessarily interfere with more important property rights. A permit issued according to prior plan avoids this problem. The legislature must have intended that solar rights accrue only after issuance of a permit.

Because the legislature has declared that solar rights are to be regulated by state law, local authorities cannot create their own regulatory systems without specific legislative authorization. The Act contains no such authorization or clear delegation to the local government to create permit systems. The State has thus preempted any local law regulating solar rights. 
The draf tsman of the Act, as well as the legislator who introduced it, interprets the Act to require that a solar access permit be obtained before a solar right can be recognized [135]. This seems to be the general view of those most closely involved in passage of the statute.

A deputy attorney general has, however, offered a contra-interpretation. It is as follows: the Act recognizes a property right to use the sun's rays. A right in the absence of regulation is still a right. One cannot say that a property right does not exist because it is not regulated. The Act has empowered local zoning authorities to regulate solar property rights just as any other property right is regulated by the zoning laws. Until solar rights are so regulated, disputes arising over solar access are to be solved using the concepts of "beneficial use" and "prior appropriation" [136], regardless of issuance of any permit.

Both of these interpretations are reasonable constructions of the text of the Act. A court adopting a supportive stance might agree that a solar right exists even in the absence of regulation, and attempt to resolve a dispute utilizing thr prior appropriation and beneficial use concepts. At this point the court would encounter a second major problem with the Act: the Act does not require that water law principles be used in adjudicating disputes over solar access. In fact, language requiring such a link was deleted from the original bill by the legislature. Although a court might be persuaded to imply such a link, the manner in which the Act defines the terms "prior appropriation" and "beneficial use" bears no relationship to similar water law definitions. Furthermore, both definitions are vague. The beneficial use definition states that:

Beneficial use shall be the basis, the measure, and the limit of the solar right, except as otherwise provided by written contract. If the amount of solar enargy which a solar collector user can beneficiully use varies with the season of the year, then the extent of the solar right shall vary likewise. [138]

One might argue that the Solar Rights Act definition of a "solar collector" in terms of Btu performance $(25,000$ on a clear winter solstice day) [137], established the measure of beneficial use and distinguished between solar "toys" and efficient systems. The weakness of this argument lies in the language of the definition itself. Although the Act, in one sentence, declares a solar collector to mean any device or system capable of collecting not less than $25,000 \mathrm{Btu}$, the very next sentence states:

The term also includes any substance or device which collects colar energy for use in:

- the heating or cooling of a structure or building

- the heating or pumping of water

- industrial, commercial, or agricultural processes

- the generation of electricity. [138]

The statute's use of the phrase, "The term also includes," is unfortunate, because it leads to the interpretation that a solar collector is one that collects over 25,000 Btu of energy, or is used to heat water, generate electricity, etc. The phrase minimizes the impact of the performance requirement established in the preceding sentence. 
The term "prior appropriation" as defined by the Act also is rather inscrutable:

(2) Prior appropriation. In disputes involving solar rights, priority in time shall have the better right except that the State and its political subdivisions may legislate, or ordain that a solar collector user has a solar right even though a structure or building located on neighborhood property blocks the sunshine from the proposed solar collector site. Nothing in this paragraph shall be construed to diminish in any way the right of eminent domain of the State or any of its political subdivisions or any other entity that currently has such a right.

This paragraph seems to say that persons may establish a solar right which can stop a major development on surrounding property. Such a provision, if taken to logical extremes, may be counterproductive to the solar commercialization effort.

Moreover, this paragraph seems to state that governments may declare that a solar right exists, even if an existing building shades a proposed collector site. A Fif th Amendment "taking" question therefore arises. Does the legislature suggest that the government may condemn privately owned land for the benefit of solar users? Who is to pay the just compensation required by such an action? The taxpayer?

A final problem with the statute is raised by paragraph $B(3)$ which states:

(3) Transferability. Solar rights shall be freely transferable within the bounds of such regulation as the Legislature may impose. The transfer of a solar right shall be recorded in accordance with Chapter 71, Article 2 (71-2-1 to 71-2-11), NMSA 1953 (the general rewording statute).

Does this section mean in the absence of transferability laws enacted by the Legislature that solar rights are not transferable? If they are transferable until regulated, another more serious question develops. Could one speculate in sun rights? For instance, if solar rights exist regardless of whether a solar collector exists, could one buy rights from nonsolar users and thus control future solar development? Can one transfer sun rights separately from the real estate itself? If so, will subsequent owners be without a sun right?

Faced with interpreting this rather muddled statute, a court might be sorely tempted to find some scheme to send the measure back to the legislature for clarification. A ruling that the Act is unconstitutionally vague and incapable of giving adequate notice would serve this purpose.

In summary, the New Mexico Solar Rights Act suffers acutely from the problem of vague and ambiguous definitions. Important terms as "permit systems," "beneficial use," and "solar rights," are ill-defined, if defined at all. No clear delegation to local governments of the power to regulate solar access.through permit systems can be found, thus adding to the confusion generated by inadequate definition. Moreover, the lack of a clear delegation has rendered local ordinances dealing with solar access subject to preemption attacks. Inattention to delegation and definition has rendered the Solar Rights Act almost unintelligible, and therefore incapable of effective implementation.

Recognizing the weakness of the Act, persons responsible for the bill's implementation have requested that the Act be amended so as to clearly indicate the legislature's intent. However, the success of any amendment to the Act is uncertain because of hostility to the solar rights concept on the part of developer interests [139]. 


\subsubsection{Income Tax Credit for Residential Applications}

In 1975, the New Mexico State Legislature enacted N.M. STAT ANN 8 72-15A, which allows a taxpayer to claim a "tax credit (not to exceed one thousand dollars $\$ 1,000$ ) in an amount equal to twenty-five percent (25\%) of the cost of equipment used in the taxpayer's principal residence" for solar heating and cooling [140]. If the allowable tax credit exceeds the taxpayer's liability, then the excess may be refunded [141]. The statute defines solar equipment as:

any heating, cooling, or heating and cooling equipment which meets the definitive performance criteria prescribed pursuant to the provisions of the Solar Heating and Cooling Demonstration Act of 1974 (42 U.S.C.A. Sec. 5.506 ), or any amendments thereto. [142]

The statute does not specifically delegate responsibility to any administrative agency, for administering or drawing regulations to implement the tax credit. The statute is embodied with Article 13 of the New Mexico code, which covers all tax laws. Contained within Article 13 [143], is a provision that authorizes the New Mexico Bureau of Revenue to draw all regulations necessary to implement the New Mexico tax code. Since the solar tax credit statute is contained in the tax code, the New Mexico Department of Taxation and Revenue is responsible by implication, for administering the tax credit.

Relying on its authority, the Department of Taxation and Revenue has promulgated rules governing the tax credit [144]. The regulations permit both active and passive devices to be eligible for the tax credit. As of 1977, the Department had received approximately 280 claims for solar tax credits. In that same year, approximately $57 \%$ of these tax credits were for active systems and $43 \%$ for passive systems [145].

Although the tax credit program seems to be running smoothly at this time, a latent defect in the way the statute defines solar equipment could change this situation. The statute defines solar equipment as that "conforming with the performance criteria developed under the Federal Solar Heating and Cooling Demonstration Act." This references the HUD Interim Performance Criteria [146]. The HUD interim performance criteria does not make provision for passive solar equipment, at least not for the types of equipment currently eligible for the New Mexico tax credit under the administrative guidelines. Therefore, approximately $50 \%$ of the tax credits extended in New Mexirn can be challenged as ultra vires, or beyond the scope of the statutory definition of solar equipment. This difficulty is apparent from the text of the regulations themselves. All active components are required by the regulations to be in conformance with HUD interim criteria, whereas the definitions contained in the regulations of passive systems do not reference that act.

The statute can also be criticized because it makes no provision for linking the research and development efforts of the Energy and Metals Department with implementation of the tax credit. By neglecting explicitly to delegate responsibility for administering the credit, the statute insured that it would, by implication, be administered by the state taxing agency. This choice can be criticized because the taxing agency may not possess the expertise necessary to evaluate and assess solar system technology [147]. Therefore, a statutory link with the DEM that has such expertise would be useful.

The statute affects intergovernmental coordination by providing that a taxpayer may not claim New Mexico credit if he has claimed a similar federal tax credit [148]. A taxpayer, therefore, must choose between a federal tax credit and the state credit, since 
the state credit amounts to only $\$ 1,000$ and the federal credit to approximately $\$ 2,200$. A taxpayer with federal tax liabilities greater than $\$ 2,200$ will undobtedly choose the federal credit, precluding himself from applying for the state credit. On the other hand, a poorer taxpayer without much federal tax liability will take advantage of the state tax credit, because of the state credit's rebate clause. The provision is commendable because it frees the state government from duplicating the federal credit for the more affluent, while at the same time providing the state's poorer taxpayers with the rebate.

\subsubsection{Solar Irrigation Pumping Credit}

In 1977, the state legislature enacted a statute allowing residents to claim a $\$ 25,000$ income tax credit for the "cost of equipment used for the construction of solar energy systems for irrigation pumping purposes" [149]. In order to be eligible for the credit, the system must have received approval from the Department of Energy and Minerals prior to installation. The system must also receive certification from the Department af ter installation, that the system "will result in a 75\% reduction in the utilization" of fossil fuels or electricity [150].

The statute fails to specifically delegate to an administrative agency the responsibility to issue regulations implementing the program. It, like the residential tax credit statute, is contained with the state tax code article. Responsibility for administration can be imputed to the State Department of Revenue and Taxation. Thus, the statute creates a split delegation-the DEM to certify, the Tax Department to administer. Responsibiliby for drawing guidelines is not, therefore, clear cut.

More importantly, the statute does not define equipment eligible for the credit or reference any existing definition. Could a pumphouse be heated with solar energy and a tax credit extended?

These problems are, at this point, mostly academic. No tax credit for a solar irrigation system has yet been claimed in New Mexico. They do illustrate, however, potential problems and pitfalls to be avoided in drafting solar legislation.

The New Mexico solar legislation scheme seems to have been enacted without any firm direction. The statutory package contains multiple definitions, each statute defining (or failing to define) important terms in the same manner. The tax credit statute has adopted definitions by reference to federal performance criteria which are too inflexible and do not include passive systems.

The state energy agency has a statutory role in administering the solar irrigation pumping credit (for which no applications have been made), and the Special Energy Fund. It has no role in administering the core of the New Mexico solar program-the Solar Rights Act income tax rebate. 


\section{SEPI亳}




\section{SECTION 6.0}

\section{CONCLUSIONS}

This article has attempted to identify several common problems in state solar legislation that hinder its effectiveness. They are: inadequate definition of important terms; ineffective or unclear delegation of administrative responsibility to state agencies; and insufficient coordination with other state and federal solar programs.

Drafting (or amending) solar legislation that avoids these difficulties is not a simple task. An awareness of their existence is the first step in their solution. Every state must to some extent confront its problems differently, depending upon its own needs and desires. This paper hopefully provides some assistance to drafters of solar laws in their efforts to create effective solar programs and initiatives. 


\section{SERI}




\section{SECTION 7.0}

\section{REPERENCES}

1. Energy Report to the States, National Conference of State Legislators (1978).

2. See, e.g., Cal. Pub. Res. Code, $\$ 25200$ et. seq. (Supp. 1978).

3. See, e.g., Fla. Stat. Ann. Sec. 255.254 (1975).

4. Energy Report, supra note 1, at 4.

5. State Solar Legislation, National Solar Heating and Cooling Information Center (1978).

6. See, e.g., Idaho Code Sec. 63-3022C (Supp. 1978); Ariz. Stat. Ann. Sec. 84-2016.8 et. seq. (Supp. 1977); Colo. Rev. Stat. Sec. 39-22-122 (Supp. 1977); Mass. Ann. Laws Ch. 63, Sec. 384 (1978).

7. See, e.g.; Ariz. Rev. Stat. Sec. 43-128.04 (Supp. 1977); Alaska Stat. Ann. Sec. 43.20.38 (1977); Cal. Rev. \& Tax Code Sec. 17052.5 (Supp. 1978); Kan. Stat. Ann. Sec. 79-32, 166-167. (Supp. 1977); N.M. Stat. Ann. Sec. 72-15A-11.2 (Supp. 1977); Haw. Rev. Stat. Sec. 235-12 (1976).

8. See, e.g., Tex. Tax. Gen. Ann. Art. 1201 (Vernon) (Supp. 1978).

9. Energy Report, supra note 1 at 14 .

10. Or. Rev. Stat. Sec. 407.048 (1977).

11. Mass. Ann. Laws 171 Sec. 240 (Supp. 1978).

12. Cal. Health and Safety Code, $\$ 17959$ (Supp. 1978).

13. For an excellent overview of barriers to solar development, see U.S. Dept. of Energy, Legal Barriers to Solar Heating And Cooling of Bulldings (1978).

14. Supra note 1 at 28 .

15. See, e.g., Or. Stat. Ann. Sec. 215.110 (g) (Supp. 1977).

16. N.M. Stat. Ann. 70-80-1 (Supp. 1978).

17. Major laws include: The Solar Heating and Cooling Demonstration Act of 1974, 42 U.S.C. Sec. 5501 et. seq.; The Non-Nuclear Energy. Research and Development Act of 1974, 42 U.S.C. Sec. 5901 et. seq.; The Solar Energy Research Development and Demonstration Act of 1974,42 U.S.C Sec. 5551 et. seq.

18. 92 Stat. $3117,3174,3206,3289,3350$.

19. P.L. 95-618, 92 Stat. 3174 (approved Nov. 9, 1978). 
(ii

20. U.S. Dept. of Housing and Urban Dev., Intermediate Minimum Property Standards For Solar Heating And Domestic Hot Water Systems (1977).

21. Supra note 17.

22. Article VI, cl. 2.

23. Schwartz, Constitutional Law, A Textbook, at 40 (1972).

24. MeCulloch v. Maryland, 4 Wheat. 316, 436 (1819).

25. The federal action must of course itself be constitutionally permissible; that is, within the scope of the Federal Government's enumerated powers.

26. Gibbons v, Ogden, 9 Wheat 1 (187.4).

27. Amalgamated Association of Street, Electric RY and Motor Coach Employees v. Lockridge, 403 U.S. 274 (1971).

28. 312 U.S. 52 (1941).

29. Id. at 67 .

30. 350 U.S. 497 (1956).

31. Id. at 502-505.

32. See, e.g., City of Burbank v. Lockheed Air Terminal, Inc., 411 U.S. 624 (1974).

33. 413 U.S. 405 (1973).

34. Id. at 413 , quoting Schwartz v. Texas, 344 U.S. 199, 202-03 (1952).

35. Summary of conference action on HR 5037, December 1977.

36. Supra note 34 .

37. Article I, sec. 8.

38. Raymond Motor Trans. Inc. v. Rice, 98 S. Ct. 787 (1978), citing, Cooley v. Board of Wardens, 12 How, 299 (1852); A. P. Tea Co. v. Cottrell, 424 U.S. 366 (1976).

39. Id. ât 793, citling, H. P. Hood and Sons, Inc. v. DuMond, 336 U.S. 521, 531 (1949).

40. See Pike v. Bruce Church, Inc., 397 U.S. 137 (1970).

41. South Carolina State Highway Dept. v. Barnwell Rros., Inc., 307 U.S. 177 (1938).

42. Raymond Motor Trans. Inc. supra note 38 .

43. Id. at 797 . 
44. A challenge to regulations or criteria which apply only to a specific incentive is, of course, considerably weaker.

45. U.S. Energy Administration, Survey of Solar Collector Activity (1977).

46. See, e.g., The Wall Street Journal, Energy, Jobs and Black America (Jan. 12, 1978) $\$ 25$ Or. Rev. Stat. Sec. 469.030 (1977).

47. Or. Rev. Stat. Sec. 469.020 .

48. Id. Sec. $307.175(1)$.

49. Or. Rev. Stat. Sec. 469.165 (1977).

50. Id. Sec. 160.160 .

51. Id. Sec. 469.170.

52. Or. Rev. Stat. Sec. 316.116 (1977).

53. Id.

54. Or. Rev. Stat. 407.048 (1977).

55. Id. (3).

56. The following definitions and comments taken, in large part, from those proposed by $W$. Thomas et. al., in Overcoming Legal Uncertainties About Use of Solar Energy Systems, American Bar Foundation (1978). An excellent reference for those drafting solar legislation. Compare Or. Rev. Stat. Sec. 469.160 (1977) (standards) with Or. Rev. Stat. Sec. 407.048 (veteran's loan).

57. Adapted from Minn. Stat. Ann. Sec. 1161-1.127 (1976). See Or. Rev. Stat. Sec. 469.160 .

58. Id. 307.175 .

59. Id. Sec. $407.030(2)$.

60. Id. Sec. 306.111 .

61. Id. Sec. 307.175

62. Or. Stat. Ann. Sec. 407.048 (2).

63. From an interview with A. E. Kaphut, Oregon Attorney General's Office.

64. Or. Stat. Ann. Sec. 469.165 (2) (1977).

65. 42 USC Sec. 5506 et seq. 
66. See, e.g., An Interview with Governor Edmund G. Brown, Jr., conducted on Meet The Press, February 26, 1978. Transcripts available from Kelly Press, Inc., Box 8648, Washington, D.C. 20011.

67. Governor's Office, State of California, State Solar Energy Program (1978).

68. Id.

69. Executive Office of the President, Energy Policy Planning, The National Energy Plan 3 (1978).

70. Cal. Pub. Res. Code Sec. 25600 et seq. (Supp. 1978).

71. Id.

72. Id. Sec. 25601 (c).

73. Id. Sce. 25606.

74. Id. Sec. 25607.

75. Id. 25605.

76. Id. 25605 (b).

77. Id. 25608.

78. Cal. Rev. \& Tax Code 17052.5 (Supp. 1978).

79. Id. 17052.5 (2).

80. Cal. Rev. \& Tax Code 23601 (Supp. 1978), exlends the identical solar tax credit to corporations.

81. Cal. Rev. \& Tax Code 17052.5 (h) (Supp. 1978).

82. Cal. Health \& Safety Code 17959 (Supp. 1978).

83. Cal. Health \& Safety Code 50680 et seq.

84. Id. 50885 .

85. Id. 50681 .

86. Cal. Rev. \& Tax Code 234 (Supp. 1978).

87. Cal Pub. Res. Code 25600 et seq. (Supp. 1978).

88. Id. 25600.

As used in this chapter: (a) "Passive thermal system" means a system which utilizes the structural elements of a building and is not augmented by mechanical components to provide for collection, storage, and distribution of solar energy or 
coolness; (b) "Semipassive thermal system" means a system which utilizes the structural elements of a building and is augmented by mechanical components to provide for collection, storage, and distribution of solar energy or coolness; (c) "Solar device" means the equipment associated with the collection, transfer, distribution, storage, and control of solar energy; (d) "Solar system" means the integrated use of solar devices for the functions of collection, transfer, storage, and distribution of solar energy.

89. Ch. 168, Cal. Stats. 1976.

90. Cal. Health and Safety Code Sec. 17959 (1978).

91. Id. Sec . 50680 et seq.

92. Ch. 168, Cal. Stats. 1976 .

93. See discussion accompanying notes 107 through 108 , infra.

94. Ch. 886, Cal. Stats. 1976. The identical definition is used in the statute extending the credit to corporations. Cal. Rev. \& Tax Code Sec. 23601.

95. Cal. Rev. \& Tax Code 17052.5 (a) (2).

96. Id. Sec. 17052.5 (a) (5). The Act states that eligible conservation measures include, but are not limited to, ceiling, wall and floor insulation above that required by law at the time of the building's construction, or water heater installation jackets, shower or faucet flow reducing devices.

97. Id.

98. Information derived from personal interviews with Solar Office Staff. A brief discussion of the issue is also contained in Solar Age, June 1978 at 29.

99. California Energy Commission Alternatives Division Solar Office, Interim Guidelines and Criteria for a State Solar Energy Tax Credit (January 5, 1978).

100. Id. $\$ 2606$.

101. Id. \$2608.

102. Although the administrative regulations themselves do not specify that a maximum credit can be obtained for each system, the administrators are interpreting the Act to allow such. See, e.g., D. Bainbridge and M. Hunt, California's New Solar Tax Credit, Solar Age at 29 (June 1978). The authors were special consultants to the Solar Office.

The fact that a maximum credit for separate solar systems is being allowed was also confirmed by the Solar Office's legal counsel during an interview conducted during the summer of 1978.

103. Supra note 99 , Sec. 2604. 
III

104. The Act does however define a solar system as being one with a useful life of at least three years. See supra note 99.

105. Standing to challenge of the regulation could be obtained by a taxpayer group, a consumer required to undertake conservation measures, or a manufacturer wishing to challenge the warranty requirement, especially those that cannot warrant that their product will be installed correctly.

106. Note 102, supra.

107. Ch. 1159,1978 Cal. Stats.; to be codified at Cal. Rev. \& Tex Code Sec. 17052.5 and Sec. 23601.

108. Id. Sec. 17052.5 (i) (6) (A) (B).

109. Cal. Pub. Res. Code Secs. 15600 et seq. (Supp. 1978).

110. Id. Sce. 25605 (c).

111. See Cal. Rev. 7 Tax Code Sec. 17052.5 (i) (Supp. 1976).

112. Id.

113. This sequence of events was pieced together from interviews conducted with ERDC staff persons during July of 1978.

114. Cal. Rev. \& Tax Code Sec. 17052.5 (g) (Supp. 1978).

115. Ch. 1, 1978 Cal. Stats.; to be codified at Cal. Health \& Safety Code Sec. 50681.

116. Cal. Pub. Res. Code Sec. 25608 (Supp. 1978).

117. Cal. Rev. \& Tax Code Sec. 17052.5 (j); 23601 (h) (Supp. 1978).

118. Cal. Pub. Res. Code Sec. 25600 (1978).

119. It will also serve as an "adequate standard" limiting agency discretion, thus legally validating the delegation. Ch. 225, 1977 N.M. Laws.

12ủ. Iâ. sèc. 3 .

121. Ch. 169,1977 N.M. Laws.

122. Taos and Los Alamos.

123. N.M. Stat. Ann. Sec. 72-15A-11.3 (Supp. 1975).

124. Id.

125. N.M. Stat. Ann. Sec. 72-15A-11.4 (Supp. 1977).

126. N.M. Stat. Ann. Sec. 65-12-1 et seq. (Supp. 1978). 
127. Id. Sec. 65-12-3 (Supp. 1975).

128. Ch. 347,1977 N.M. Laws.

129. 1977 N.M. Stat. Ann. Sec. 65-12-4 (Supp. 1975).

130. Id. Sec. 65-12-7.

131. Solar Rights Act

70-8-1. Short Title.

This act [70-8-1 to 70-8-5] may be cited as the "Solar Rights Act."

70-8-2. Declaration and findings.

The legislature declares that the state of New Mexico recognizes that economic benefits can be derived for the people of the state from the use of solar energy. Operations, research, experimentation and development in the field of solar energy use shall therefore be encouraged. While recognizing the value of research and development of solar energy use techniques and devices by governmental agencies, the legislature finds and declares that the actual construction and use of solar devices, whether at public or private expense, is properly a commercial activity which the law should encourage to be carried out, whenever practicable, by private enterprise.

70-8-3. Definitions.

As used in the Solar Rights Act [70-8-1 to 70-8-5]:

A. "solar collector" means any device or combination of devices or elements which rely upon sunshine as an energy source, and which are capable of collecting not less than 25,000 Btus on a clear winter solstice day. The term also includes any substance or device which collects solar energy for use in:

(1) the heating or cooling of a structure or building;

(2) the heating or pumping of water;

(3) industrial, commercial or agricultural processes; or

(4) the generation of electricity.

A solar collector may be used for purposes in addition to the collection of solar energy. These uses include, but are not limited to, serving as a structural member or part of a roof of a building or structure and serving as a window or wall; and

B. "solar right" means a right to an unobstructed line-of-sight path from a solar collector to the sun, which permits radiation from the sun to impinge directly on the solar collector.

70-8-4. Declaration of solar rights.

A. The legislature declares that the right to use the natural resource of solar energy is a property right, the exercise of which is to be encouraged and regulated by the laws of this state. Such property right shall be known as a solar right.

B. The following concepts shall be applicable to the regulation of disputes over the use of solar energy where practicable:

(1) "beneficial use". Beneficial use shall be the basis, the measure, and the limit of the solar right, except as otherwise provided by written contract. If the amount of solar energy which a solar collector user ean beneficially use varies with the season of the year, then the extent of the 
solar right shall vary likewise;

(2) "prior appropriation". In disputes involving solar rights, priority in time shall have the better right except that the state and its political subdivisions may legislate, or ordain that a solar collector user has a solar right even though a structure or building located on neighborhood property blocks the sunshine from the proposed solar collector site. Nothing in this paragraph shall be construed to diminish in any way the right of eminent domain of the state or any of its political subdivisions or any other entity that currently has such a right; and

(3) "transferability". Solar rights shall be freely transferable within the bounds of such regulation as the legislature may impose. The transfer of a solar right shall be recorded in accordance with Chapter 71, Article 2 [71-2-1 to 71-2-11], NMSA 1953.

C. Unless singular overriding state concerns occur which significantly affect the health and welfare of the citizens of this state, permit systems for the uso and application of snlar energy shall reside with county and municipal zoning authorities.

70-8-5. Prior rights unaffected.

Nothing in the Solar Rights Act [70-8-1 to 70-8-5] shall be construed to alter, amend, deny, impair or modify any solar right, lease, easement or contract right which has vested prior to the effective date of the Solar Rights Act [70-8-1 to 70-8-5].

132. See, e.g., S. Kramer, Solar Law, at 157 (1978):

133. See, e.g., Fountainebleau Hotel Corp. v. Forty-Five Twenty-Five Inc., 114 So. 2 d. 357, 181 Fla. Supp. 74 (1959).

134. N.M. Stat. Ann. Sec. 70-80-3 (B) (Supp. 1977).

133. Bused upon interviews with Ropresentative Vernnn Kerr, Act Sponsor; and Gary Güi:isün, Act Draftaman, conduoted by SERI staff during July 1978.

136. From an interview with Nick Gentry conducled by 3ERI staff during July 1878.

137. N.M. Stat. Ann. Sec. 70-8-3 (A) (Supp. 1977).

138. Id.

139. Information derived from interviews with the legislators who introduced the Act, conducted in October 1978 by the author.

140. N.M. Stat. Ann. Sec. 72-15A-11.3.

141. Id. Sec. (F).

142. Id. Sec. (E).

143. N.M. Stat. Ann. Sec. 72-13-23 (Supp. 1975).

144. S.T.C. Regulation 11.3 (A) et seg. 
145. Revenue Review, New Mexico Taxation and Review Department, No. 16, Sept. (1978).

146. Supra note 20 .

147. The regulations for the solar tax credit were drawn by a single individual in the Department of Revenue and Taxation. That individual is now employed by the Department of Energy and Minerals.

148. N.M. Stat. Ann. Sec. 72-15A-11.3 C. (Supp. 1975).

149. Id. Sec. 72-15A-11.4 (Interim Supp. 1976-77).

150. Id. B (2), formerly the Energy Resources Board; changed by N.M. Stat. Ann. Sec. 70-8-4 (B) (1). (Interim Supp. 1976-77). 


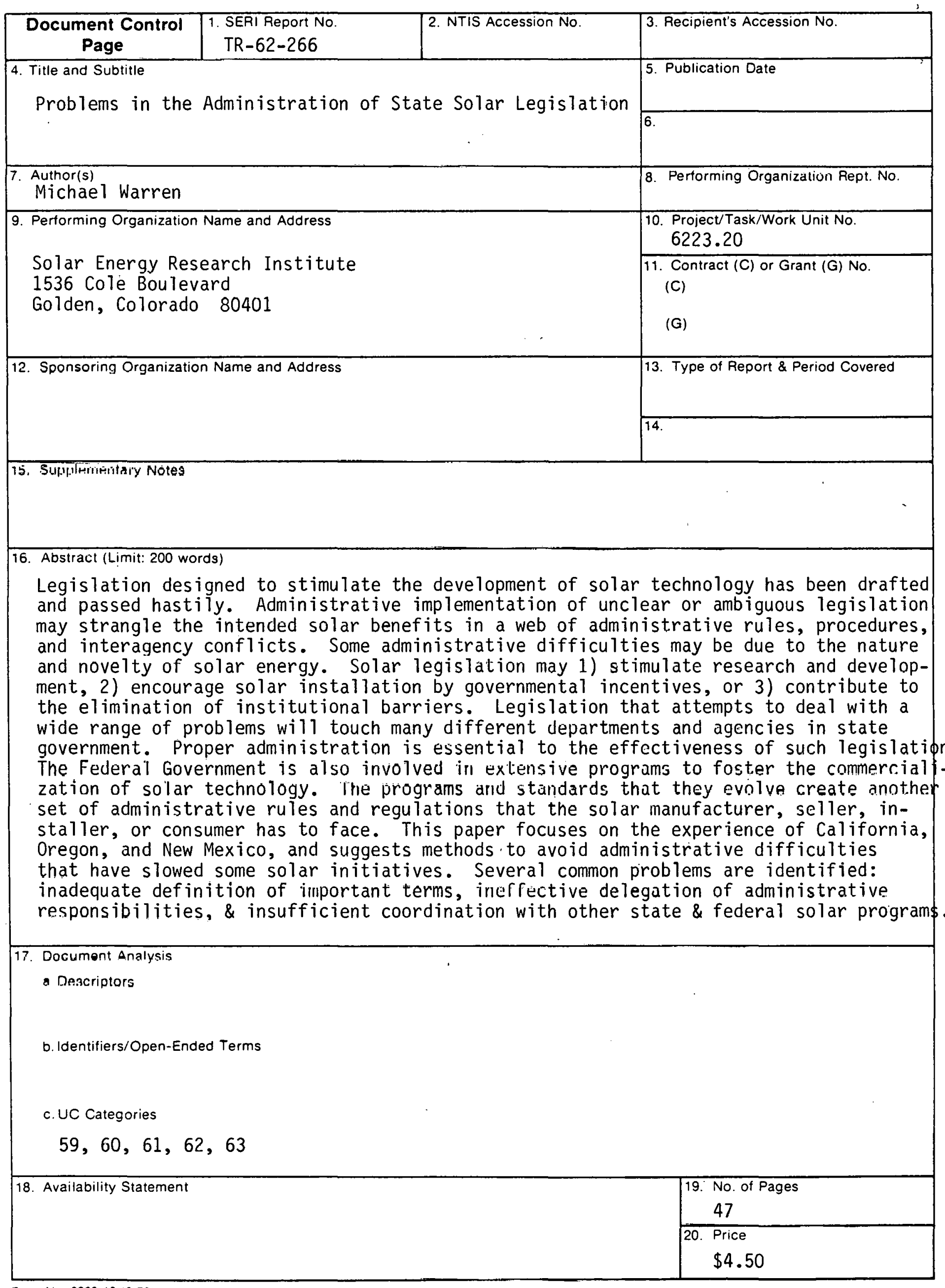

